\title{
Meeting of Wisconsin Normal School Teachers of Geography, Madison, January 23, 1920
}

\section{R. H. Whitbeck}

To cite this article: R. H. Whitbeck (1920) Meeting of Wisconsin Normal School Teachers of Geography, Madison, January 23, 1920, Journal of Geography, 19:3, 115-116, DOI: 10.1080/00221342008984866

To link to this article: http://dx.doi.org/10.1080/00221342008984866

曲 Published online: 22 Feb 2008.

Submit your article to this journal $₫$

Џ Article views: 2

Q View related articles $\asymp$ 
The Pupils' Owa List of Essentials

Another plan has been used with much success. The pupils are told to write the names of all places mentioned and pointed out in class each day. Near the end of the term or at certain intervals, each pupil makes a list of those places which he considers of enough importance to locate. Then the lists are compared and discussed in class and from all the lists a list is made which the class thinks is essential. The importance of a place has to be shown clearly before it is put on the list. A list of places made in some such manner appeals strongly to the pupils because they have made it.

Occasionally it is a good plan to give a blank map to the pupils and have them locate a few places. Five or ten minutes spent in this way at certain times will stimulate the pupils, and the teacher can ascertain whether he is successfully teaching place geography.

\section{MEETING OF WISCONSIN NORMAL SCHOOL TEACHERS OF GEOGRAPHY, MADISON, JANUARY 23, 1920}

It is a rare thing for normal school teachers to hold a separate and äistinet educational meeting, but it was done in Wisconsin, January 22 to 24,1920 . Over 250 teachers attended. One section was devoted to geography. Several papers and lively discussions made up an interesting program. A committee was appointed and funds provided to carry on a state-wide campaign of education for the purpose of stimulating interest in the study of geography.

- Following is a list of questions submitted for discussion:

Questions Submitted for Discussion at the Madison Meeting of the Wisconsin Normal Teachers of Geography

FUNCTION

1. What is the central organizing thought in Geography?

VaLues

2. What is the bearing of the study of Geography under modern citizenship? 
3. Will a reconstruction and resuscitation of the subject of Geography in the state ever take place until those who are interested in the cause organize a campaign of propaganda upon its value and place in elementary and secondary education?

\section{The Course of STUdY}

4. How much Geography should be required of every student?

5 . What proportion of the time should be spent on methods? On academic work? On place Geography? On regions outside of the United States?

6. Should there be a course in Geography common to all as a prerequisite to the course which specializes for primary, grammar, high school, or rural groups?

7. In what respects should the courses for grammar, primary, and rural groups differ?

8. What should be the content of the course in Geography for Normal School students, both as to subject matter and method?

9. Should electives in Geography be given before the introductory course? Should credits for courses thus taken be convertible into eredits for the basic course?

10. What should be taught in the way of a geographical interpretation of the war?

\section{Methods}

11. What is the place and value of the problem-project method in Geography?

12. What other methods, devices, and suggestions can be used for vitalizing the study of Geography?

13. In what grade should Geography begin? Should it be independent or correlated? Should it have as much time as in the upper grades? Should it be begun through the natural product series or through the natural phenomenon series?

\section{Relation to Training Schools}

14. How may the work in Geography in the Normal School best be made to function in the Training School?

\section{Relation to State Department}

15. Should we attempt to get the State Department to allow us to prepare a new outline for the Wisconsin state manual?

16. Ought not the Normal School instructors in Geography to be doing more work in the County Institutes?

17. What can be done to stimulate the teaching of Geography in the grades?

R. H. WHITBECK 